\title{
TPP, trade-off and eco-system establishment in Taiwan
}

\author{
Jiann-Chyuan Wang ${ }^{1 *}$, Joe-San Lee ${ }^{1}$ and Yu-Chun Ma
}

\author{
${ }^{*}$ Correspondence: \\ jcw@cier.edu.tw \\ ${ }^{1}$ Chung-Hua Institution \\ for Economic Research, \\ 75 Chang-Hsing St., Taipei, \\ Taiwan \\ Full list of author information \\ is available at the end of the \\ article
}

\begin{abstract}
The Trans-Pacific Partnership (TPP) is a free trade agreement with high standards, affecting multiple industries, and imposing tremendous economic impacts. The TPP accounts for $36 \%$ of world GDP and its significance and impacts are profound, specifically affecting tariff reduction in the manufacturing sector, market entry in the service sector, and rules of origin requirements, as well as currency valuation, intellectual property rights, and even immigration. This means that Taiwan cannot view the TPP lightly. Taiwan's economy is export-focused, so not being able to partake in regional economic integration will exert an unfavorable impact on Taiwan's trade expansion and investment attractiveness. Taiwan's government should therefore actively seek to engage in the second round of TPP discussions. Although President Trump has announced that the US will be withdrawing from the TPP, Japan is seeking further consolidation so that the remaining TPP member countries can continue to make progress. Taiwan cannot exert much control over international opposition to Taiwan's membership of the TPP on the part of other countries, so this paper focuses mostly on the challenge of overcoming domestic opposition. A review of the literature reveals that the benefits of joining the TPP outweigh the harm; however, despite continuous efforts to promote the TPP and the reaching of consensus within governmental organizations, there has still been a considerable backlash against the idea of TPP membership from many groups in society. This is because TPP membership would directly disadvantage thousands of domestic-orientated businesses, small and medium enterprises (SMEs), and the younger generation. This means that TPP promotion needs to be more considerate of the interests of all related parties and be undertaken in an 'eco-system'-like manner, focusing on helping traditional industries, SMEs, the agricultural sector, and young people. In addition, the government should work on strengthening the skills of existing workers, and work to develop a system that keeps capital and skilled labor within the country. Foreign investment should ideally help to stimulate domestic economic growth, create more employment opportunities, and drive wages up. If these benefits can be emphasized, then the promotion of the TPP or other FTAs is likely to encounter less resistance and receive more support from Taiwan's citizens.
\end{abstract}

Keywords: TPP, Trade-off, Eco-system, Small and medium enterprises (SMEs), Agriculture, Youth

\section{Background}

The Trans-Pacific Partnership (TPP) is a proposed regional free trade agreement (FTA) being negotiated among the United States, Australia, Brunei, Canada, Chile, Japan, Malaysia, Mexico, New Zealand, Peru, Singapore, and Vietnam. US negotiators and

(c) The Author(s) 2017. This article is distributed under the terms of the Creative Commons Attribution 4.0 International License (http://creativecommons.org/licenses/by/4.0/), which permits unrestricted use, distribution, and reproduction in any medium, provided you give appropriate credit to the original author(s) and the source, provide a link to the Creative Commons license, and indicate if changes were made. 
others describe and envision the TPP as a "comprehensive and high-standard" FTA that aims to liberalize trade in nearly all goods and services and include rules-based commitments beyond those currently established in the World Trade Organization (WTO).

The deadlock in the WTO Doha Round trade talks provided stimulus for the creation of regional trade groupings, and there is now a clear trend towards the forming of such regional trade blocs. Of particular concern for Taiwan's future economic development are a group of large-scale regional integration initiatives in the Asia region, including: (1) the TPP agreement; (2) the Regional Comprehensive Economic Partnership agreement (RCEP). The RCEP initiative has been led by China, so that Taiwan has only a very slim chance of being able to participate in the RCEP. In contrast, TPP initiated by the US, which is more friendly to Taiwan, so Taiwan has better chance to involve in the second round negotiation. In addition, the TPP member economies combined account for $36 \%$ of global GDP, so Taiwan cannot afford to ignore the potential impact of the TPP (Wang 2015).

The TPP's 12 member economies have already completed the accession negotiations, and a formal agreement was signed in New Zealand on February 4, 2016. However, shortly after President Trump took office in January 2017, he announced that the US will be withdrawing from the TPP.

Despite President Trump's decision to withdraw from the TPP, the TPP's high-standard regulations, for example in the areas of intellectual property rights, state-owned enterprises, immigration, and so on, will continue to serve as a benchmark for other FTAs. Even though President Trump announced his decision to withdraw USA's participation in TPP, however, for an export-oriented country like Taiwan, joining FTA or TPP is a necessary evil and must decision. Furthermore, participating TPP's negotiation, benefits, and impacts will be a valuable experience for Taiwan to go through other FTA negotiation. Moreover, Japan is still seeking further consolidation among the remaining TPP member countries.

From Taiwan's point of view, as an export-oriented economy which is highly dependent on foreign trade, failure to secure participation in the process of regional economic integration could lead to trade diversion, and make it more difficult for Taiwan to secure foreign investment. For this reason, Taiwan's government has expressed strong interest in participating in the second round of TPP negotiations. Oppositional forces exist in Taiwan however, resulting from divided domestic public opinion (especially regarding the importation of American beef and pork, and importation of agricultural products from areas affected by radiation in Japan), and there is also international opposition originating from Vietnam in particular (Vietnam's export earnings derive mainly from textiles, petrochemical products and footwear, and these happen to be among Taiwan's strengths, so Vietnam does not want Taiwan to join the TPP).

Another potential problem concerns China's stance. Negotiations regarding accession to the TPP are dependent on group consensus, so it is foreseeable that China may try to influence other countries to oppose Taiwan's inclusion in the TPP. This means that Taiwan needs to consider this possibility and have mechanisms in place to counter it. On the other hand, Taiwan's new administration is relatively pro-US, and therefore (assuming that the US does not withdraw from the TPP) if Taiwan manages to meet the demands imposed by the US or Japan and gain their approval, the chances of Taiwan joining the TPP successfully should increase. Taiwan can do little to influence 
international opposition to its membership of the TPP, but domestic divided opinion can be reconciled, so this paper will focus on issues that are rectifiable.

The US government has made it clear that Taiwan will not be allowed to take part in the negotiations unless it agrees to allow entry of US pork products into Taiwan's market. ${ }^{1}$ At the same time, the pressure to open markets will have a severe negative impact on many of Taiwan's traditional industries, and on the agricultural sector. Serious thought needs to be given as to how to build consensus in favor of TPP membership, and to the design of ancillary measures that will be required once market opening begins, the final goal being to build a comprehensive TPP "eco-system" in Taiwan (Chinese National Association of Industry and Commerce 2016).

The TPP eco-system participants would include both those industries that will benefit from TPP membership and those that will be negatively impacted, such as small and medium enterprises (SMEs), young people, etc. To secure widespread support for TPP membership, there is a need to implement suitable response measures and ancillary and supporting measures with respect to those industries that will suffer as a result of TPP membership.

There is also a need to put in place mechanisms to encourage the flow of human talent, capital and technology back to Taiwan, so that Taiwanese firms' overseas investment can contribute to economic growth and job creation within Taiwan.

The main purpose of this paper is to explore both the negative impacts and the benefits of TPP membership for Taiwan, and to suggest how a suitable eco-system could be established, paying due attention to the interests of all concerned parties, so as to make the process of promoting Taiwan's participation in the TPP a smoother one. The paper is divided into five sections. Following this introduction, "Research methodology" section elaborates on the research methodology. "Negative impacts and benefits of TPP membership for Taiwan" section examines the benefits that securing TPP membership would bring for Taiwan, and also the negative impact. "Results and discussions: eco-system establishment and balancing the interests of different parties" section presents the research results and a discussion, which examines the types of ancillary measures that need to be put in place, and the kind of eco-system that needs to be built up, taking into account the interests of all related parties. "Conclusions" section summarizes the paper's conclusions.

\section{Research methodology}

This paper mainly discusses the impact of the TPP on Taiwanese industry, and the steps and strategies that should be adopted if Taiwan hopes to join the TPP. The methodology used in this paper includes a literature review, secondary data analysis, and analysis of government policy regarding TPP accession. In the literature review, we cover the content of the TPP, and the pros and cons of TPP accession as well as the anticipated response from non-members of the TPP. We also cite simulation results deriving from assumptions made in suitable scenarios to demonstrate the possible impacts of joining the TPP. This will show the macroeconomic impacts for both joining the TPP and not

\footnotetext{
${ }^{1}$ After US withdrawal from TPP, Japan takes the lead in TPP. Japan may ask Taiwan to import Fukushima's products into Taiwan to take part in TPP negotiation.
} 
joining the TPP as well as the industries that would be most affected if Taiwan joined the TPP. $^{2}$

Secondly, observations deriving from seminars and from interviews with experts, government officials etc. are also incorporated in our research methodology.

Finally, some policy recommendations are put forward as to how the government should convince the general public of the need for TPP membership and how it can minimize the negative impact on industries that will be affected the most. These recommendations are based on the authors' observations from FTA seminars and industry surveys of related parties.

\section{Negative impacts and benefits of TPP membership for Taiwan}

The TPP is a FTA, which involves tariff reductions in the manufacturing sector, market opening in the service sector, and strict rules of origin (ROO) requirements. The TPP member economies combined account for 36\% of global GDP, and 34.82\% of Taiwan's total trade value, so Taiwan cannot afford to ignore the potential impact of the TPP. Taiwan's government has been implementing the Free Economic Pilot Zones (FEPZs) ${ }^{3}$ as a first step towards liberalization and deregulation, with the ultimate goal being to secure membership of the TPP.

TPP has the following four features: "full liberalization, deregulation, comprehensiveness and advancement" (see Fig. 1). It has no exclusions, comprehensively covering SME supply chain management, extensive deregulation (including inner border rules, telecommunications, and state-owned enterprises etc.), as well as advancement on emerging issues agreements. These features can thus serve as a benchmark for future FTA negotiations. Joining the TPP would therefore have both benefits and disadvantages for Taiwan. An examination of the literature in this area suggests that, while securing TPP membership would be beneficial for Taiwan as a whole, it would have a significant negative impact on certain industries and on many of Taiwan's small and medium-sized enterprises (SMEs) (Capling and Ravenhill 2011; Faunce and Townsend 2011).

\section{Benefits}

The TPP was designed to cut tariffs and expand market access for exporters within the twelve signatory nations. However, the TPP is expected to go beyond these traditional elements, creating "twenty first century" rules in areas such as services, investment, digital commerce, state-owned enterprises (SOEs) and environmental protection. Trade today is less about arm's length transactions among importers and exporters and more about adding value to transnational supply chains. Modern trade agreements need to reduce friction and establish realistic rules regarding supply chains, including behindthe-border barriers in member economies, to produce real economic benefits (Green and Goodman 2016).

From Taiwan's point of view, the potential impact of TPP membership on Taiwan's economy can be analyzed from the following five perspectives. Firstly, TPP membership

\footnotetext{
${ }^{2}$ The paper is analyzed with US participation. Without US participation, the benefit will much less. However, TPP can still serve as a guideline for Taiwan's negotiation with other countries on FTAs.

${ }^{3}$ It should be noted that the FEPZs legislation has not yet been passed by the Legislative Yuan (Taiwan's legislature).
} 


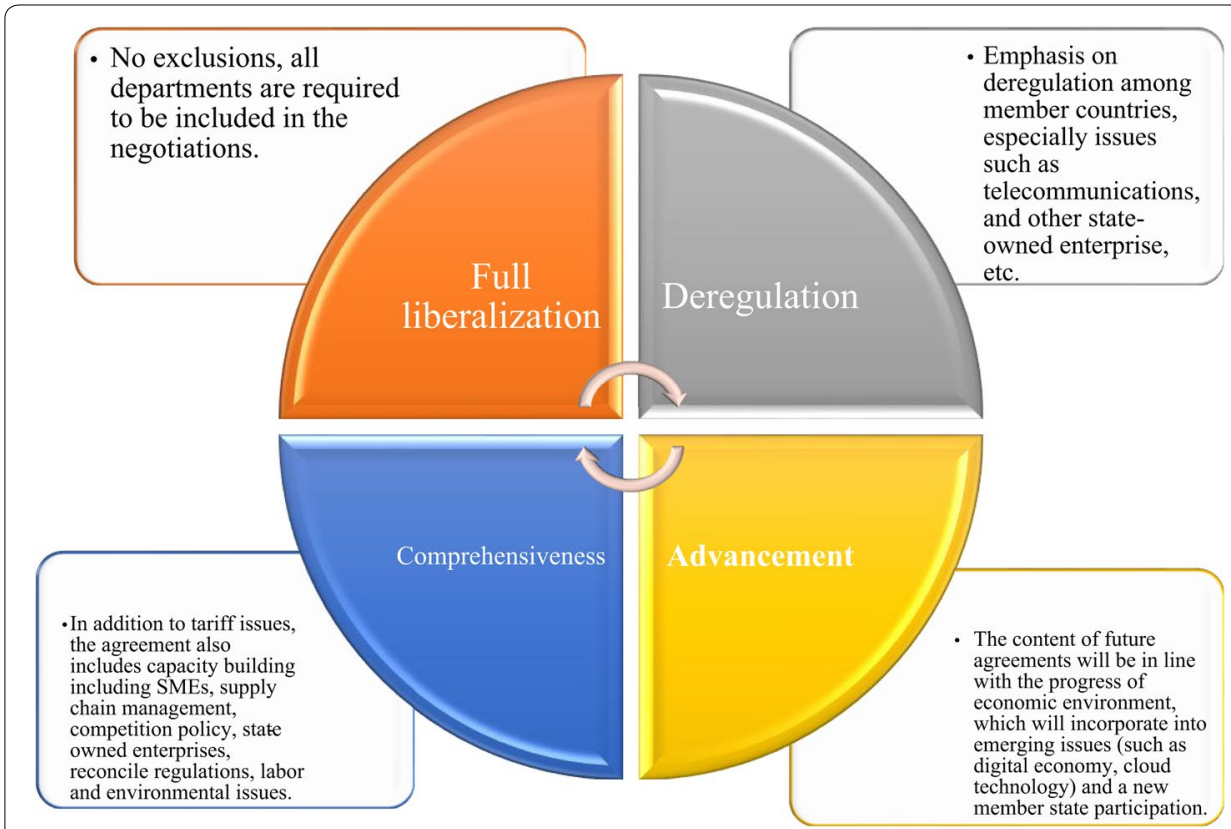

Fig. 1 The key features of the TPP agreement. Source: Ministry of Economic Affairs (MOEA), Taiwan

should help Taiwan's companies to expand their market share in the global market as a whole.

The 12 TPP signatory nations combined account for a major share of global GDP: 36\% in the year 2014. It can reasonably be assumed that TPP membership would enable Taiwanese firms to increase their market share in the global market as a whole whilst avoiding being marginalized in the trend of international integration.

Secondly, securing membership of the TPP would help Taiwan to maintain its crucial role in the global supply chain. The 12 TPP member economies account for around $34.82 \%$ (US $\$ 204.7$ billion) of Taiwan's total trade value. If Taiwan fails to secure membership of the TPP, given the TPP's strict rules of origin (ROO) requirements, other countries can be expected to reduce the amount of goods that they import from Taiwan for re-export to fellow TPP member economies. This could seriously threaten Taiwan's role in the global supply chain, particularly for the textile, automotive component and bicycle industries. According to industrial surveys, most of Taiwan's manufacturing industry associations believe that Taiwan should attempt to secure admission to the TPP, but some service industry associations hold a more conservative view towards TPP participation.

Thirdly, for Taiwan's economy as a whole, the benefits from TPP membership would outweigh the disadvantages. According to analysis presented in a report compiled by the Bureau of Foreign Trade, Ministry of Economic Affairs in 2015, securing membership of the TPP could be expected to boost Taiwan's GDP by $1.95 \%$, increase annual output by $1.91 \%$, and boost employment by $0.65 \%$ (based on analysis of 57 sectors, and 129 major economies; the GTAP 8.0 database was used for numerical simulation) (see Fig. 2). In addition, TPP membership would have significant positive benefits in terms of strengthening Taiwan's position within the global supply chain, bringing Taiwan more closely 


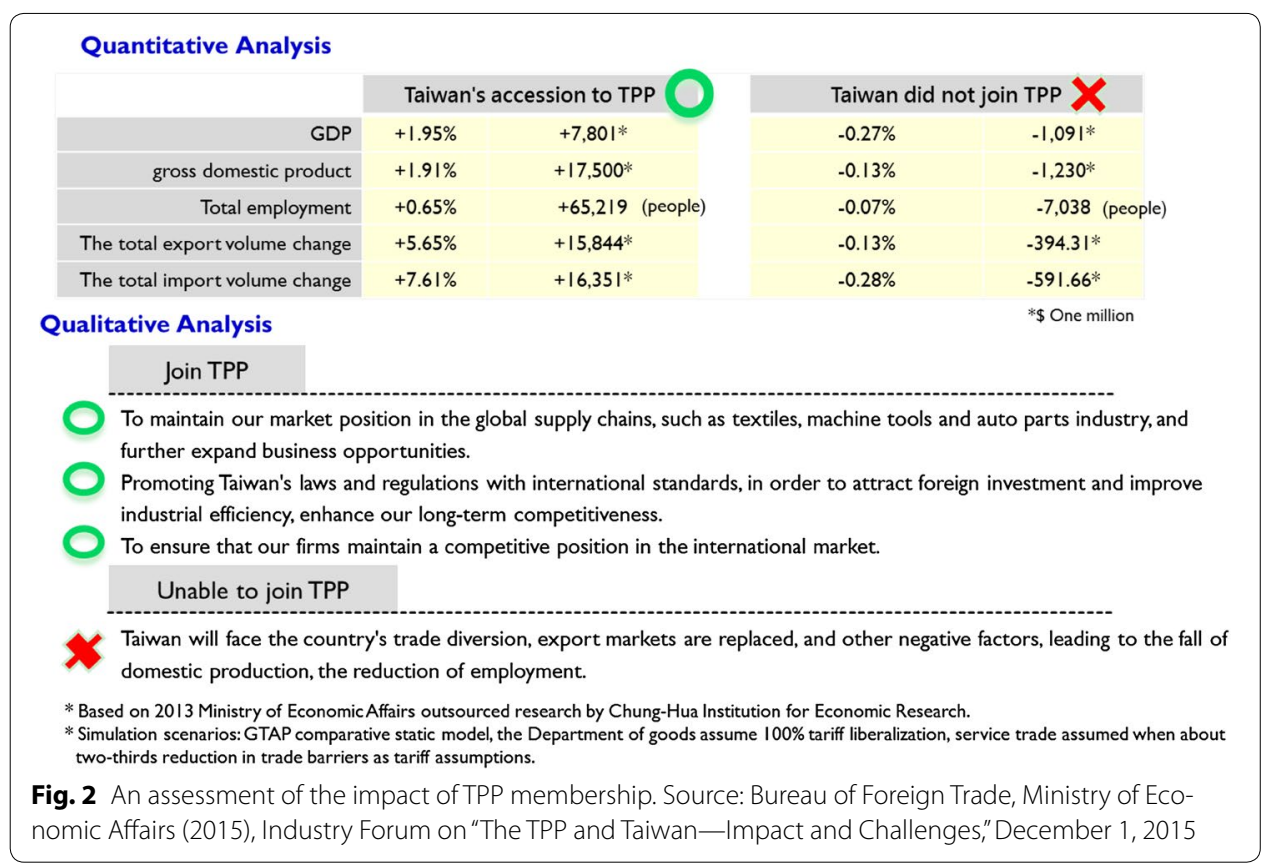

into line with normal international regulatory practice, and attracting foreign investment, etc.

Fourthly, securing TPP membership would help to strengthen Taiwan's links with other Asia Pacific region economies. Signing the TPP agreement would not only lead to both acceleration and deepening of Taiwan's linkage with the Asia Pacific regional economy as a whole, but would also protect Taiwan from excessive dependence on the Chinese economy. The high level of dependence could lead to loss of independent diplomatic and political leverage (Green and Goodman 2016).

A fifth aspect is that the market opening and deregulation that would accompany TPP membership would contribute to enhanced efficiency in many areas. The TPP is a "highstandard" trade agreement, under which tariffs must be reduced to zero on $95 \%$ of product items; this would have a pronounced impact on those Taiwanese industries which do not possess competitive advantage. In addition, the need to implement market opening in the service sector would force Taiwan to undertake planning and adjustment with respect to those service industries which are not competitive in international terms, such as telecommunications and financial services, as well as in relation to environmental protection and labor issues, etc. In this way, TPP membership would help Taiwan to achieve greater harmonization with standard international practice; over the long term, this would further enhance the benefits to Taiwan from TPP membership, and reduce the negative impacts.

\section{Impacts}

Tsai (2015) noted that becoming a member of the TPP could have significant negative effects on Taiwan's agricultural sector and on industries engaged in the processing of agricultural products. In addition, signing the TPP agreement can also be expected to cause substantial difficulties for the social services, telecommunications services and 
healthcare services industries, which in turn could lead to a reduction in job opportunities, particularly for young people (Wang 2014).

Table 1 shows that electronics industries may suffer from TPP. However, since July 1, 1997, tariffs on IT and communications devices, semiconductors, electronic components, etc. (excluding electronics for domestic consumption) have been reduced by the same rate, reaching a zero tariff in 2000 after four stages of tariff reduction. Taiwan has already joined the WTO's Information Technology Agreement (ITA) covering information technology products, and the vast majority of electronics and electronic products exported to international markets already do not incur tariff costs; therefore, in the short-term, whether Taiwan joins the TPP or not can be expected to have less of an impact on the electronics sector.

On the other hand, if Taiwan does not secure membership of the TPP, then it will suffer the following serious negative impacts:

Firstly, Taiwan's exports will be severely disadvantaged in regard to tariffs (Chinese National Federation of Industries 2015). Approximately 35\% of Taiwan's manufacturing sector export products are liable to import duty in TPP member economies, with products liable to import duty of more than 5\% representing approximately $13 \%$ of Taiwan's total exports. In the Chilean, Australian and Vietnamese markets, more than $60 \%$ of Taiwan's export product items are liable to import duty, in most cases at a rate of $5 \%$ or higher. Overall, tariff barriers in the US market are not as high as in the ASEAN member states; however, the US ranks second highest among the TPP member economies in terms of the total value of Taiwan's exports that are liable to import duty.

Secondly, the TPP's rigorous ROO requirements would have a major impact on Taiwan's place within the international supply chain if Taiwan is unable to secure membership of the TPP (Chinese National Federation of Industries 2015). In order to comply with ROO requirements, other countries that are TPP members and have been involved

Table 1 The ten industries that would benefit most from Taiwan's accession to the TPP, and the ten industries that would be most negatively impacted (Source: Chien et al. (2015), citing Hsu (2012), "A quantitative analysis of the potential impact of TPP and RCEP membership on Taiwan," APEC Newsletter, No. 159)

\begin{tabular}{lllc}
\hline Industries benefiting most & $\begin{array}{l}\text { Change } \\
\text { in output }\end{array}$ & $\begin{array}{l}\text { Industries suffering } \\
\text { the biggest negative impact }\end{array}$ & $\begin{array}{c}\text { Change } \\
\text { in output }\end{array}$ \\
\hline $\begin{array}{l}\text { Man-made fibers and glass } \\
\text { fiber textiles }\end{array}$ & 123,676 & Semiconductors \\
Other textiles & 43,380 & Applicable machinery \\
Petroleum refining tablets & 39,276 & $\begin{array}{l}\text { Other special machinery and equip- } \\
\text { ment }\end{array}$ & $-17,996$ \\
Knitted fabrics & 39,086 & Optical materials and components & $-15,607$ \\
Cotton and cotton textiles & 35,810 & Slaughtering and meat by-products & -9651 \\
Petrochemical raw materials & 25,838 & Metalworking machinery & -8708 \\
Residential services & 25,838 & Precision instruments & -7255 \\
Leather & 23,985 & Industrial machinery and equipment & -5839 \\
Wholesaling & repair and installation & -5824 \\
Plastics (synthetic resin) & 19,863 & Other electronic components & -4535 \\
\hline
\end{tabular}


in the processing of Taiwanese goods for further processing and re-export are expected to reduce the amount of materials that they import from Taiwan and turn to other suppliers that are TPP members instead; this could have a severe impact on Taiwan's exports, and could disrupt the role that Taiwan currently plays within the supply chain.

Thirdly, Taiwan's business enterprises may be forced to relocate their operations outside Taiwan (Chinese National Federation of Industries 2015). For example, bicycle manufacturing is an industry in which Taiwan has enjoyed competitive advantage for many years. If Taiwan fails to secure membership of the TPP, Taiwan's leading bicycle makers (such as Merida and Giant) may find themselves facing high tariffs averaging $7.55 \%$ in TPP member economies, with import duty in the range of $3.7-11 \%$ in the US market, which is Taiwan's single biggest export market, accounting for 19\% (US\$686 million) of Taiwan's total annual bicycle exports. Several Taiwanese manufacturers have indicated that, once the TPP agreement comes into effect, they are unlikely to be able to stay in business for more than 2 years $^{4}$; if Taiwan is unable to secure membership of the TPP, they will be forced to close down their production operations in Taiwan and relocate production overseas.

In the textile sector, the TPP member economies constitute important export markets for Taiwan; here, Taiwan would be faced with high tariffs averaging $6.42 \%$. Vietnam is a particularly important export market, accounting for $17.8 \%$ (US\$2.057 billion) of Taiwan's total textile exports. Securing membership of the TPP would help to boost Taiwan's textile exports; failure to secure membership would result in Taiwanese exporters having to face high tariffs on exports of yarn and fabric (the average import duty would be $11.55 \%$ in the case of Vietnam, and $9.31 \%$ in the case of the US) as well as strict ROO requirements, leading to a reduction in exports. Taiwanese textile manufacturers in the upstream segment of the industry might be forced to relocate production overseas.

\section{Results and discussions: eco-system establishment and balancing the interests of different parties \\ Final results}

After reviewing the literature, the potential impact of TPP on Taiwan can be summarized as follows.

Firstly, TPP membership should help Taiwan's companies to expand their market share in the global market as a whole. Secondly, securing membership of the TPP would help Taiwan to maintain its crucial role in the global supply chain. Thirdly, for Taiwan's economy as a whole, the benefits from TPP membership would outweigh the disadvantages. Analysis shows that securing membership of the TPP could be expected to boost Taiwan's GDP by $1.95 \%$, increase annual output by $1.91 \%$, and boost employment by $0.65 \%$; TPP membership would also lead to an increase in both imports and exports. Fourthly, securing TPP membership would help to strengthen Taiwan's links with other Asia Pacific region economies. A fifth aspect is that the market opening and deregulation that would accompany TPP membership would help to bring Taiwan more closely into line with normal international practice, and contribute to enhanced efficiency in many areas.

\footnotetext{
${ }^{4}$ According to remarks made by a representative of the Taiwan Manufacturing Association during his speech in a TPP forum, and comments made in interviews with reporters.
} 
However, the TPP will also have a negative impact on Taiwan's semiconductor, general-purpose machinery, "other specialist machinery," and optoelectronic materials and components industries, as well as the agricultural sector. In addition, signing the TPP agreement can also be expected to cause substantial difficulties for the social services, telecommunications services and healthcare services industries, which in turn could lead to a reduction in job opportunities, particularly for young people.

\section{Discussion}

There is little that Taiwan can do to overcome international opposition to Taiwan's membership of the TPP on the part of other countries, but the divergence of opinion within Taiwan itself can be reconciled to build consensus; the main focus of this discussion will therefore be on resolving domestic pressure. ${ }^{5}$ As analyzed above, securing TPP membership for Taiwan will bring more benefits than costs. However, the trade-off between industries that will benefit from TPP membership and industries that will be harmed by it is a crucial factor. Moreover, there is currently widespread doubt among the general public in Taiwan regarding both the advisability of the government's supporting measures and its ability to execute these measures effectively. The government will therefore need to build up a sound eco-system and take effective measures to help industries and groups that would suffer from TPP membership, so as to silence the anti-TPP groups. In this section, we will go on to discuss how to establish an appropriate eco-system and balance the different groups' interests.

\section{Why is opposition to TPP membership still so vocal?}

Given that the overall benefits to Taiwan from TPP membership would far outweigh the negative impacts, and that the government has already established effective mechanisms for overseas lobbying and domestic communications, along with relevant ancillary and supporting mechanisms, why is there still so much opposition to TPP membership in Taiwan? The main reasons for this situation can be summarized as follows:

Firstly, there is the question of opening up Taiwan's domestic market to beef and pork imports, and the question of Ractopamine (a feed additive used to promote leanness in animals raised for their meat): In other countries, it has been found that including Ractopamine in the feed of beef cattle and pigs can reduce farmers' production costs by around 10\% (Central News Agency 2016). If Taiwan's market is fully opened to overseas beef and pork imports, sales of domestically-produced beef and pork will be negatively impacted; Taiwan's beef cattle and pig farmers are thus naturally opposed to TPP membership. An additional issue here relates to eating habits in Taiwan, where consumption of pork per capita is very high, accounting for around $50 \%$ of total meat consumption (Lin 2016), which is significantly higher than the corresponding percentages for Japan or South Korea.

\footnotetext{
${ }^{5}$ It is fundamentally in the strategic and economic interest of the US for Taiwan to join the TPP, and if Beijing seeks to isolate Taiwan, the next US administration will need to signal that it is committed to helping Taiwan to join the TPP; however, such action on the part of the US would be accompanied by expectations of strong statements of commitment to the TPP from the Taiwanese government and of Taiwan making a "down-payment" in the form of liberalization measures.
} 
Furthermore, Taiwanese people eat considerable quantities of pork intestines; for example, pregnant women are frequently given dishes such as pig kidneys cooked in sesame oil to eat as restorative foods to build up their strength; allowing the importation and consumption of pork from pigs that had been given Ractopamine as a feed additive could threaten the health of unborn children. Given the opposition from pig farmers and cattle farmers, the opposition from ordinary consumers, and the exploiting of this issue by politicians for electoral purposes, it is clear that it will be difficult for Taiwan to meet the main condition set by the US for the possibility of TPP membership for Taiwan: relaxing restrictions on the import of US beef and pork products into Taiwan.

The United States or Japan will definitely ask Taiwan to permit these imports before TPP negotiations even begin, and this would cause a serious dilemma for Taiwan. Taiwan is likely to compromise on this issue to avoid being marginalized by China, and to achieve greater participation in regional economic integration. Currently, Taiwan's government has been assessing the impact that importing American pork would have on Taiwan's agricultural sector and how to deal with the potential consequences. It is important for Taiwan to restructure the pork production industry and only allow importation within specified limits at first, before gradually increasing import quotas over time until imports are fully opened up; in this way, it should be possible to minimize the harm caused to the domestic industry.

Secondly, although the overall benefits to Taiwan from TPP membership would outweigh the overall negative impact, the benefits will not be evenly distributed. Estimates compiled by the Taiwan Institute of Economic Research (TIER) that were cited in the United Daily News in 2015 (see also Table 1 in this paper) indicate that the industries that would benefit most from TPP membership are the man-made fiber, textile-weaving and oil-refining industries. By contrast, TPP membership would have a pronounced negative impact on Taiwan's semiconductor, general-purpose machinery and other machinery-related industries. In addition, the agricultural and processing sectors, and various service industries oriented towards the domestic market, will also be negatively affected. The resulting vocal opposition from affected industries and groups has influenced attitudes towards TPP membership among the population as a whole.

The key issue for the government will be to get the various related parties, and particularly those groups that will be negatively affected by TPP membership (including young people, traditional industries, SMEs and farmers) to appreciate the benefits that TPP membership would bring, and to find ways to minimize the negative impacts and compensate those affected. The extent to which Taiwan is able to successfully build consensus regarding the negotiation of TPP membership (or other FTAs) will thus depend on how well Taiwan is able to put in place an "eco-system" in which no related party feels that its interests are being sacrificed.

A third factor is lack of confidence in the government. The potential benefits that would result from the signing of the ECFA agreement between Taiwan and China were over-hyped; in the event, the impact of the global financial crisis that began in 2008, and of the European bond crisis that began in 2010, undermined what benefits the ECFA agreement might have brought. Real estate prices and consumer retail prices in Taiwan have been rising steadily for some years now, while wages have remained stagnant; adding to this the intensity of political competition between the government and 
the opposition and growing hostility towards China among the general public, there has been a crisis of confidence in relation to the government's perceived effectiveness. The negative reaction to the ECFA agreement has undermined people's faith in the government in regard to the negotiation of the TPP and other FTAs, and the general public as a whole is dubious about the government's ability to effectively manage the market opening and related ancillary and supporting measures that TPP membership would require.

\section{The "Eco-system"}

The fact that so many different related parties would be affected by TPP membership means that a first-class TPP promotion "eco-system" is needed in order to ensure effective implementation of the government's efforts to secure membership of the TPP for Taiwan. What is meant here by "eco-system" is a "group of interconnected elements engaged in the joint creation and sharing of value" (Executive Yuan 2016). The TPP promotion eco-system would thus include both those industries that will benefit from TPP membership and those that will be negatively impacted, as well as SMEs, young people, etc. To secure widespread support for TPP membership, there is a need to implement suitable response measures and ancillary and supporting measures with respect to those industries that will suffer as a result of TPP membership (particularly those industries oriented towards Taiwan's domestic market), SMEs, and young people, as well as a need to put in place mechanisms to encourage the flow of human talent, capital and technology back to Taiwan, so that Taiwan's firms' overseas investment can contribute to economic growth and job creation within Taiwan.

(A) Communication with the members of the eco-system: building consensus within society

For an export-oriented economy like Taiwan, having low tariff rates, a multilingual environment and an open trade policy are vital. The path that Taiwan needs to follow involves the use of education to spread awareness, communicate and reach people, so that Taiwan's citizens cease to be afraid of TPP membership and adopt a more proactive attitude towards it. In the past, environmental education efforts in Taiwan were very effective at getting Taiwan's citizens to adopt a more responsible attitude towards environmental sustainability, sorting garbage, and recycling.

In the future, similar methods will be needed to win over the public and secure their support for signing the TPP agreement. Getting a wide range of related parties (including public associations, industry associations, the general public, government officials, legislators, etc.) involved at an early stage would also help to build consensus and reduce opposition. Consideration should be given to adopting the citizen participation model, with the utilization of "citizen meetings" or "consensus-building meetings" of the type first developed in Denmark, which provide a venue for free and open discussion, and which can help ordinary citizens to develop a better understanding of the issues involved, so that a consensus can be formed based on adequate information and rational communication. 
(B) An eco-system that provides relief for the main victims of TPP membership

(a) SMEs: strengthening advance guidance and assistance

Firstly, with respect to SMEs in those industries that will be most seriously affected by TPP membership, the preliminary allocation of budgets for guidance provision should be followed by the provision of subsidies. The approach currently adopted by the government is to allocate just over NT\$90 billion in funding, together with the formulation of assistance plans for affected industries. However, in most cases applications for subsidies can only be processed after an industry has already suffered harm. If it were possible to provide industry associations and other relevant associations with funding in advance to facilitate the provision of guidance to affected SMEs, followed up by more direct subsidies at a later date, then this should help to reduce anti-TPP sentiment. SMEs in exportoriented industries generally lack the human talent, capital, and access to information needed for international marketing and overseas investment.

The provision of funding support to help these SMEs market their products overseas effectively using e-commerce should help to win increased support for TPP membership among SMEs. Taiwan may also want to consider adopting a similar approach to the "Cool Japan" strategy used in Japan, whereby outstanding SMEs are identified, and encouraged to invest overseas and market their products in international markets, with the government providing assistance by negotiating on their behalf with foreign governments, helping them secure land for overseas expansion, obtain cheaper rents, form industry clusters, and develop effective branding; the adoption of such a strategy would be sure to help Taiwan's SMEs to develop overseas markets more effectively.

It would also be advisable to hold presentations for SMEs in Taiwan, at which retired government officials, lawyers, tax specialists, labor affairs and food safety experts, and representatives of industry associations, from foreign countries are invited to talk, so as to help overcome the problems that SMEs experience in terms of lack of access to information. This would help to speed up SMEs' expansion into overseas markets, making them more enthusiastic about supporting the government's efforts to negotiate TPP membership for Taiwan.

(b) Young people: planning measures that will appeal to young people As a first step, there is the potential for the government and those Taiwanese companies interested in internationalizing their operations to collaborate on the provision of customized training programs for young people. Following the completion of their training, the trainees would be assigned by the companies involved to work overseas as management trainees or assistant store managers; this would get them involved in the process of corporate internationalization and help them develop a broader outlook. Young people working overseas would have regular opportunities to return home to Taiwan for training or vacations; in this way, there would be a two-way flow of human talent, avoiding the situation where talent only flows out in a one-way direction, leaving the country empty of talented young people. It is also important for Taiwan to continue investing in innovation and R\&D; if more companies set up R\&D facilities and IP management facilities 
in Taiwan, this will also help to stem the flow of talent overseas. Furthermore, those Taiwanese-owned businesses that have achieved success overseas should be encouraged to list on Taiwan's stock market or OTC exchange. Part of their profit can therefore be remitted back to Taiwan to maintain the face value of stock as well as help capital flow back into Taiwan. This would ameliorate concerns that increased overseas investment could lead to further hollowing out of Taiwan's economy. In this way, businesses can make a positive contribution toward fostering Taiwan's economic growth and creating job opportunities (Fig. 3).

Assuming the creation of an eco-system in which human talent, capital and technology can be seen to be flowing back to Taiwan, the benefits of free trade will be more apparent to the general public, and it will be easier to win the public's support for TPP membership. At the same time, by helping SMEs to develop international markets and make effective use of e-commerce for international marketing, and by fostering the well-planned overseas expansion of Taiwan's service industries, these measures will help more SMEs to build economies of scale and will help to drive economic growth in Taiwan.

(c) Farmers: reducing the negative impact on agriculture, compensating farmers for their losses, and helping farmers to develop export businesses

(i) Negotiating strategy

When planning Japan's negotiations to secure membership of the TPP, the Japanese government reached the conclusion that, if Japan's agricultural sector was completely liberalized, this would cause the annual production value of Japanese agriculture to fall by $30 \%$ (around 3 trillion yen). Thanks to the hard work of Japan's negotiating team, it was eventually possible to come to various arrangements in relation to tariff reduction and tariff quotas for

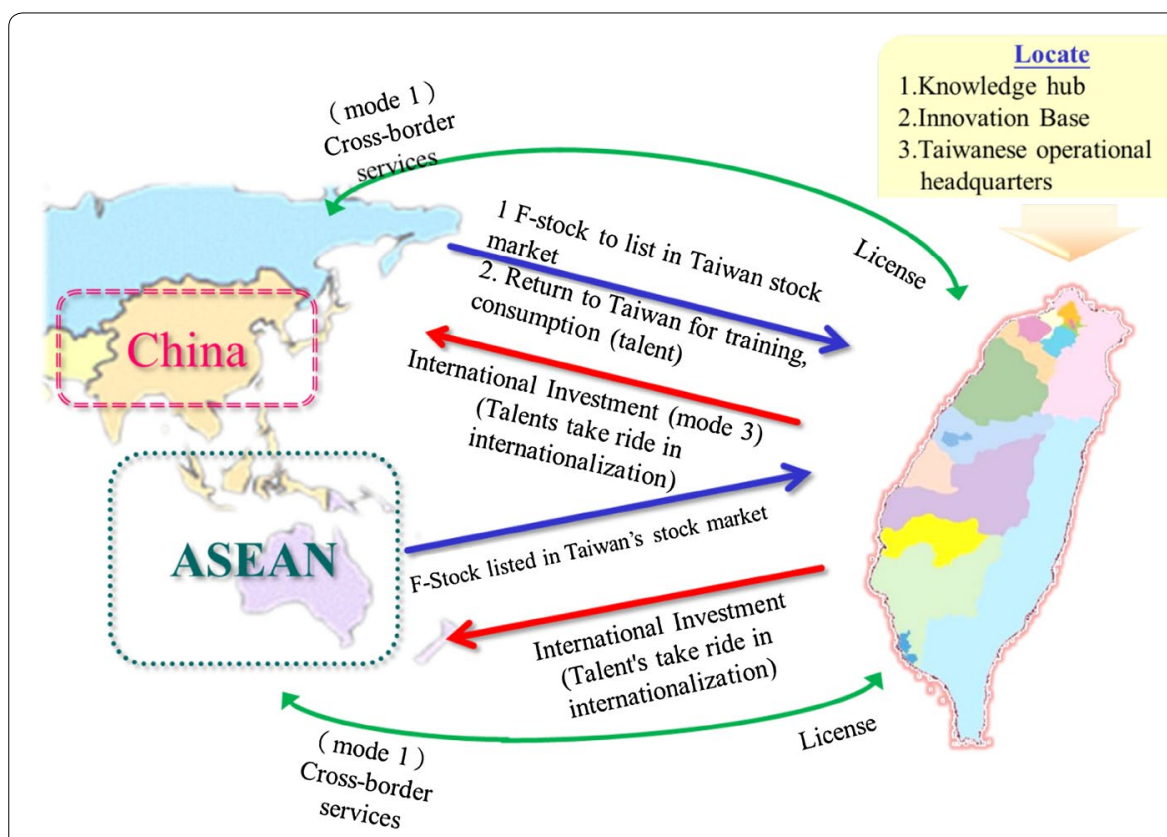

Fig. 3 Skilled labor and financial capital's recycling mechanism. Source: Collated by author 
Japan's agricultural products, so that five key categories of agricultural product were spared the complete elimination of import duty. Taiwan may want to consider adopting a similar approach when negotiating TPP membership, forming a strong negotiating team, and insisting that sensitive agricultural products be excluded from having import duty reduced to zero (in the same way as exemptions have been arranged for Japanese beef, pork, dairy products, rice, etc.); by designing a range of appropriate tariff reduction and tariff quota models, Taiwan could ensure that if, during the process of market opening, it was discovered that the tariff reductions were leading to a dramatic increase in imports that was causing harm to Taiwan's agricultural production, then tariffs could be raised to mitigate the harm (this is what is generally known as "special safeguards").

(ii) Adjusting the structure and fundamentals of the agricultural sector The most effective strategy for responding to competition from foreign agricultural products is to enhance the utilization of technology in agriculture and boost productivity while lowering production costs. To realize this adjustment of the fundamentals and the structure of Taiwan's agricultural sector, one option would be to promote the development of specialized agricultural production zones, so that resources and capital can be matched effectively to help build economies of scale. Taiwan could also seek to bring about adjustments to cultivation systems, ensure the effective utilization of land that is currently lying fallow, promote production models that allow small landowners to rent out their land to large-scale agricultural producers, and promote more effective utilization of agricultural land resources in general.

Taiwan has been promoting the "small landlords and big tenants" scheme (which encourages farmers with small plots to lease out their land for use by larger agricultural producers) for many years. Although in the past its effectiveness was limited, time has shown that this scheme represents a step in the right direction, due to reasons that include a declining rural population, an increase in the average age of farmers, and reluctance on the part of farmers' offspring to take up agriculture.

(iii) Strengthening relief for farmers negatively affected by imports If Taiwan's agricultural products are negatively impacted by imports, import relief measures can be implemented by providing farmers with meaningful compensation. This type of measure has already been adopted in Taiwan in the past following Taiwan's accession to the WTO, and proved quite effective. In the future, more active use should be made of this kind of measure.

(iv) Developing agricultural product exports

As Taiwan's trading partners reduce or eliminate their import tariffs on agricultural products, there is the potential for Taiwan to grow its exports of high-quality Taiwanese agricultural products, at the same time boosting agricultural product value-added. Strengthening the international marketing of agricultural products is thus a strategy to which Taiwan should be paying more attention. In this regard, it might be advisable for Taiwan to reference 
the models adopted in countries such as New Zealand and the Netherlands for promoting the overseas sales of their agricultural products. This would involve in-depth research and reforms targeting farmers' organizations, product $R \& D$, branded marketing strategies, etc., with the aim of ensuring that several of Taiwan's agricultural products are able to achieve impressive export sales performance within a short space of time.

(v) Encouraging the local sale of locally-produced agricultural produce and developing effective product and market segmentation

Taiwan should be working to promote the local sale of locally-produced agricultural produce, and strengthen product and market segmentation. Product traceability can help to give consumers more confidence in the quality of domestic agricultural products, while product labeling can be used to distinguish domestically-produced products from imports. Efforts should also be made to strengthen branding, stimulate product innovation, promote effective utilization of online marketing, and educate children about agricultural products and farming.

In response to the possibility that restrictions on imports of US beef and pork into Taiwan may be relaxed, effective planning of new measures in relation to the non-frozen pork and general pork supply chain, and the planning of suitable product traceability measures, can help to ensure clear differentiation of domestically-produced pork and beef and US or Canadian pork and beef products, ensuring that domestically-produced pork and beef (including both frozen and non-frozen products) can out-compete frozen US or Canadian pork and beef, thereby helping to ease the concerns of Taiwan's pig and cattle farmers.

(vi) Using direct grants to safeguard farmers' incomes

In order to avoid the inefficient misallocation of resources, measures to support the prices of agricultural products should be gradually reduced, in favor of a system of direct grants that is not tied to production volume or prices, thereby safeguarding farmers' livelihoods. As regards reform of the guaranteed rice price system, Taiwan should study the approach used by the European Union, which introduced a compensation payments system in 1992 but then gradually transitioned to a direct grant system. This kind of approach can help to avoid a lot of unwelcome side-effects.

\section{Conclusions}

Even though President Trump has announced that the US will be withdrawing from the TPP, Japan is still pushing for further consolidation among the remaining TPP member countries. Moreover, the TPP's high-standard rules and regulations can serve as a benchmark for other FTA negotiations. The TPP is therefore still an important issue for Taiwan.

Securing membership of the TPP would be highly beneficial to Taiwan from the point of view of strengthening overall export competitiveness and enhancing Taiwan's ability to attract foreign investment. However, TPP membership would also have a negative impact on certain industries (particularly those industries that are mainly oriented 
towards the domestic market), SMEs, and young people. This paper recommends that an appropriate TPP "eco-system" should be put in place to ensure that the interests of all parties are taken into account, with a particular emphasis on the provision of guidance and assistance measures for Taiwan's traditional industries, SMEs, agricultural sector, and young people.

At the same time, mechanisms to encourage the flow of human talent, capital and technology back to Taiwan should be strengthened, so that Taiwanese-owned firms' overseas investment can help to drive the growth of Taiwan's domestic economy, create new job opportunities, and boost wage levels in Taiwan. In this way, by adopting a dual-track approach, the process of winning support for TPP membership can be made smoother and more effective.

\section{Authors' contributions}

JW is responsible for research framework and relevant analysis; YM is responsible for literature review and data collection, and $\mathrm{JL}$ is in charge of agriculture policy analysis. All authors read and approved the final manuscript.

\section{Author details}

${ }^{1}$ Chung-Hua Institution for Economic Research, 75 Chang-Hsing St., Taipei, Taiwan. ${ }^{2}$ Third Research Division, Chung-Hua Institution for Economic Research, 75 Chang-Hsing St., Taipei, Taiwan.

\section{Competing interests}

The authors declare that they have no competing interests.

\section{Publisher's Note}

Springer Nature remains neutral with regard to jurisdictional claims in published maps and institutional affiliations.

Received: 26 April 2016 Accepted: 6 June 2017

Published online: 21 June 2017

\section{References}

Capling, Ann, and John Ravenhill. 2011. Multilateralising regionalism: What role for the Trans-Pacific Partnership Agreement? The Pacific Review 24 (5): 553-575.

Faunce, Thomas Alured, and Ruth Townsend. 2011. The Trans-Pacific Partnership Agreement: Challenges for Australian health and medicine policies. Medical Journal of Australia 194 (2): 17.

Central News Agency. 2016. Chen Bao-ji has three questions for the new administration about easing restrictions on US pork imports," based on a Central News Agency interview with former Minister of the Council of Agriculture Chen Bao-ji.

Chien, M.C., C.Y. Tan, and M.T. Wu. 2015. Is taiwan ready for membership of the TPP and RCEP? Taipei: New Taiwanese Cultural Foundation.

Chinese National Federation of Industries. 2015. Industry seminar on "The TPP and Taiwan: Impact and challenges". Taipei.

Chinese National Association of Industry \& Commerce, Taiwan. 2016. Building an eco-system to promote the securing of TPP membership for Taiwan, and response strategies for business enterprises. Taipei: Taipei World Trade Center (TWTC).

Executive Yuan. 2016. Taiwan bioeconomy industry development program, office of science and technology. Taipei: Executive Yuan.

Green M.J. and M.P. Goodman. 2016. After TPP: the Geopolitics of Asia and the Pacific. The Washington Quarterly 38(4):19-134

Hsu, P.H. 2012. A quantitative analysis of the potential impact of TPP and RCEP membership on Taiwan. APEC Newsletter 159: 6-7.

Lin, C.F. 2016. If Taiwan's agricultural sector Raises its productivity, there is no need to fear US pork imports. China Times Sec. 8. (January 12, 2016)

Tsai, H.M. 2015. The potential impact of TPP and RCEP membership on taiwanese industry, and some possible response strategies. In Is Taiwan ready for membership of the TPP and RCEP?, ed. M.C. Chien, C.Y. Tan, and M.T. Wu. Taipei: New Taiwanese Cultural Foundation.

Wang, J.C. 2014. paper read at the National Affairs Conference on Trade and Economics (Taipei).

Wang, J.C. 2015. How should Taiwan respond to the ongoing process of regional economic integration? Global Industry and Commerce Monthly 2014 (677): 20-26. 